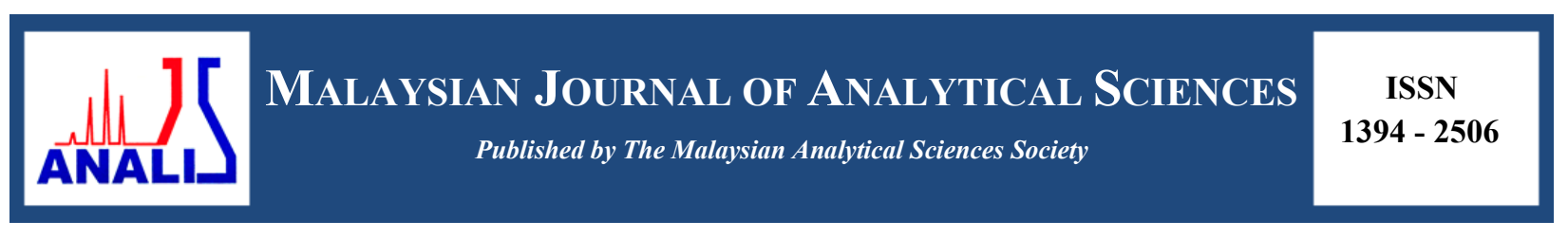

\title{
PHYTOCHEMICAL AND ANTIMICROBIAL EVALUATION OF Pithecellobium jiringa STEM BARKS EXTRACTS
}

\author{
(Penyaringan Fitokimia dan Antimikrob ke atas Ekstrak Kulit Kayu Batang Pithecellobium \\ jiringa)
}

Zurhana Mat Hussin*, Nurul Anasuhah Osman, Aiza Harun, Shaari Daud

Faculty of Applied Sciences,

Universiti Teknologi MARA Pahang, 26400 Bandar Tun Abdul Razak, Jengka, Pahang, Malaysia

*Corresponding author: zurhana_mhussin@pahang.uitm.edu.my

Received: 4 December 2016; Accepted: 1 December 2017

\begin{abstract}
Pithecellobium jiringa ( $P$. jiringa) is economically important due to its various traditional uses in treating hypertension and diabetes (seeds), medicine (leaves) and source of dye for silk (pods). This is a pioneer study that reports its effectiveness as antimicrobial agent from stem bark of $P$. jiring $a$. The present study was carried out to detect preliminary phytochemicals and antimicrobial of solvent extracts from $P$. jiringa stem bark. Qualitative phytochemical analysis was performed on ethanol and ethyl acetate extracts. These extracts were investigated for their antimicrobial activity of different microorganism tests including bacteria and fungi by using agar disc diffusion technique. Tannins, flavonoids, terpenoids and saponins were the main metabolites found in phytochemical screenings. Both ethanol and ethyl acetate extracts exhibited marked antimicrobial activity against skin disease caused-microbes Staphylococcus aureus, Staphylococcus epidermidis and Trychophyton mentagrophytes with highest inhibition zone (IZ) of $23 \mathrm{~mm}$ at $200 \mathrm{mg} / \mathrm{mL}$ ethyl acetate extracts. The current study confirmed that the stem bark of $P$. jiringa has a potential source of active antimicrobial agent. Further analysis on the isolation and characterization of compound form $P$. jiringa stem bark, responsible for antimicrobial properties is in progress.
\end{abstract}

Keywords: antifungal activity, antimicrobial activity, inhibition zone, Pithecellobium jiringa

\begin{abstract}
Abstrak
Pithecellobium jiringa ( $P$. jiringa) adalah penting dari segi ekonomi dengan kegunaan tradisional pelbagai dalam merawat tekanan darah tinggi dan kencing manis (biji), perubatan (daun) dan sumber pewarna untuk sutera (buah). Melalui kajian ini, melaporkan kali pertama, keberkesanannya sebagai agen antimikrob daripada kulit kayu batang $P$. jiringa. Kajian ini telah dijalankan untuk mengesan fitokimia awal dan antimikrob ekstrak pelarut dari kulit kayu batang $P$. jiringa. Analisis fitokimia kualitatif telah dilakukan ke atas ekstrak etanol dan etil asetat. Ekstrak ini telah dikaji untuk aktiviti antimikrob dengan ujian mikroorganisma yang berbeza termasuk bakteria dan kulat menggunakan teknik resapan cakera agar. Tanin, flavonoid, terpenoid dan saponin adalah metabolit utama yang diperolehi dari saringan fitokimia. Kedua-dua etanol dan etil asetat ekstrak mempamerkan tanda aktiviti antimikrob terhadap penyakit kulit yang disebabkan oleh mikrob Staphylococcus aureus, Staphylococcus epidermidis dan Trychophyton mentagrophytes dengan zon perencatan tertinggi (IZ) $23 \mathrm{~mm} \mathrm{pada} 200 \mathrm{mg} / \mathrm{mL}$ ekstrak etil asetat. Kajian ini mengesahkan bahawa kulit kayu batang $P$. jiringa mempunyai sumber potensi antimikrob aktif. Analisis lanjut mengenai pengasingan dan pencirian komponen kulit kayu batang $P$. jiringa, bertanggungjawab untuk ciri-ciri antimikrob sedang dijalankan.
\end{abstract}

Kata kunci: aktiviti antikulat, aktiviti antimikrob, zon perencatan, Pithecellobium jiringa 


\section{Zurhana et al: PHYTOCHEMICAL AND ANTIMICROBIAL EVALUATION OF Pithecellobium jiringa STEM BARKS EXTRACTS}

\section{Introduction}

Pithecellobium jiringa (Jack) Prain is a traditional medicinal plant belongs to the family of Leguminosae which originated from the Southeast Asia [1]. P. Jiringa is known as jering in Malaysia, djengkol in Indonesia and Luknieng in Thailand. P. jiringa is commonly consumed in Malaysia, Indonesia and Thailand. The fruit has been used to eliminate bladder stones when taken as a drink that is mixed with ginger. Traditionally, the plant is also used to treat hypertension and diabetes. The fruit rinds have been identified to be used as ingredients to make traditional soaps, shampoos and detergents. The leaves of $P$. jiringa is used to cure the itchy parts of the human body [2]. In the present day, $P$. jiringa is also being used in the production of organic pesticide as a replacement for synthetic pesticide; since the plant contains djenkolic acid that could kill and inhibit pests. Old folk has also been using its pounded leaves and bark for chest pains, skin ailments, gum pains and toothache [3].

The previous research on the extraction of leaves, pods and seeds of P. jiringa using methanol revealed the antimicrobial and antifungal activities against the microorganisms such as Staphylococcus aureus and Staphylococcus epidermidis from bacteria group while Microsporum gypsum from fungi [4]. According to Charungchitraka et al., Archidendron jiringa Nielsen lectin had shown low concentration antifungal activity against Exserohilum turcicum, Fusarium oxysporum and Colletotrichum cassiicola while Bacilus subtilis, Staphylococcus aureus and Candida albicans were observed by minimal inhibitory concentration (MIC) determination [5]. The extraction of $P$. Jiringa seed using methanol had inhibited the bacteria even at low concentration against Exserohilum turcicum, Fusarium oxysporum and Colletotrichum cassiicola. Moreover, the leaves of $P$. jiringa had showed an inhibition zone of fungi that mostly active against Staphylococcus aureus, Staphylococcus epidermidis and Microsporum gypsum at $100 \mathrm{mg} / \mathrm{mL}[1]$.

Nowadays, the high cost and non-availability of new generation antibiotics with limited effective span have encouraged the increasing in morbidity and death. Thus, a new solution must be produced from other sources with proven antimicrobial properties. As a result, this has led to the new research about the materials of plant origin to find out more effective antimicrobial agents other than to discover the potential useful active ingredients that can be used as source for the synthesis of new antimicrobial drugs and baseline to identify the active compounds that involve in this activity. The scientific value of $P$. jiring $a$ stem bark on the antimicrobial activity under this study can be used to extend its use to the community.

\section{Plant extraction}

\section{Materials and Methods}

Pithecellobium jiringa ( $P$. jiringa) stem bark was washed and kept air-dried for one week. The dried plant material was cut into small pieces, and ground twice to produce fine particles. The stem bark of $P$. jiring $a$ was weighed and soaked with ethyl acetate in ratio 1:5 (w/v) for 72 hours. The same stem bark was soaked again with ethanol with same ratio and time of extraction. The mixtures were filtrated and concentrated by using rotary evaporator at $40{ }^{\circ} \mathrm{C}$.

\section{Test microorganisms}

For antimicrobial and antifungal studies, Staphylococcus aureus, Staphylococcus epidermidis, Trychophyton mentagrohytes and Candida albicans were obtained from Biological Laboratory 3, Universiti Teknologi MARA (Pahang).

\section{Agar preparation}

Nutrient agar and Potato dextrose agar (PDA) were used for the microbiological analysis; antimicrobial and antifungal activities of the crude extract in stem bark of $P$. jiringa on the two pure cultures of bacterial and two cultures of dermatophytes. All media were prepared and sterilized on different petri dish that followed the manufacturer's specifications [6].

\section{Microbiological assay}

The fungal suspension was standardized spectrophotometrically to an absorbance optical density (OD) of 0.1 at 450 $\mathrm{nm}$ by using UV-VIS. This adjusted suspension corresponded to $0.5-2.5 \times 10^{3}$ cells $/ \mathrm{mL}$ and used as inoculums for antifungal susceptibility testing. Potato Dextrose Agar (PDA) was inoculated with Trychophyton mentagrohytes and Candida albicans by using cotton buds. Then, all discs with different concentration of ethyl acetate and ethanol 
extracts $(25,50,100$ and $200 \mathrm{mg} / \mathrm{mL})$ were aseptically transferred to the inoculated agar plates and later all the plates were incubated for two days at $37^{\circ} \mathrm{C}[6]$.

The bacterial suspension was standardized spectrophotometrically to final optical densities (OD) of 0.1 was achieved using UV-VIS at $600 \mathrm{~nm}$. These standardized OD values of inoculums were corresponding to the concentration of $1.5 \times 10^{6} \mathrm{CFU} / \mathrm{mL}$. Nutrient Agar (NA) was inoculated with Staphylococcus aureus and Staphylococcus epidermidis by using cotton buds and the plates were allowed to dry for five minutes. Then, all discs with different concentration of extracts $(25,50,100$ and $200 \mathrm{mg} / \mathrm{mL})$ were aseptically transferred to the inoculated agar plates and all the plates were incubated for 24 hours at $37^{\circ} \mathrm{C}$ [7].

The activity of microbes was determined by the presence of clear zones of inhibition around the discs. The diameter of the zone of inhibition was recorded in millimetre $(\mathrm{mm})$. Nystatin was used as standard antifungal, ampicillin (10 $\mu \mathrm{g})$ as standard antibacterial and solvent as a negative control. All determinations were carried out in triplicate [8].

\section{Phytochemical analysis}

Test for alkaloids: $1 \mathrm{~mL}$ of each filtrate of extracts was added with a few drops of the Mayer's reagent. The formation of greenish colour or cream precipitate indicates the presence of alkaloids. Test for saponins: $1 \mathrm{~mL}$ of each filtrate of extracts was mixed with $10 \mathrm{~mL}$ of distilled water. Then, the mixture was shaken vigorously for 30 seconds. The honey comb froth formation indicated the presence of saponins. Test for flavonoids: $1 \mathrm{~mL}$ of each filtrate of extracts was mixed with few pieces of magnesium strips and a few drops of concentrated $\mathrm{HCl}$. An orange faint colour of effervescence solution indicated the presence of flavonoids. Test for tannins: $1 \mathrm{~mL}$ of each filtrate of extracts was added with three drops of ferric chloride solution. A blue black or blue green precipitate was taken as evidence for the presence of tannins. Test for terpenoids: $1 \mathrm{~mL}$ of each filtrate of extracts was added with $2 \mathrm{~mL}$ of chloroform. $3 \mathrm{~mL}$ of concentrated $\mathrm{H}_{2} \mathrm{SO}_{4}$ was carefully added to form a layer. A reddish brown colouration of the interface indicates the presence of terpenoids.

\section{Results and Discussion}

Antimicrobial assays of ethanol and ethyl acetate extracts of $P$. jiring $a$ stem bark were screened against bacteria and fungi. Antifungal activity was investigated using two fungal strains Trichophyton mentagrophytes and Candida albicans as shown in Table 1. The ethanol and ethyl acetate extract showed the maximum diameter of inhibition zone 18.0 and $23.0 \mathrm{~mm}$ against Trichophyton mentagrophytes at $200 \mathrm{mg} / \mathrm{mL}$ and showed no inhibition against Candida albicans. The results of both the extracts were correlated with the standard drug thus showed that the ethyl acetate extracts had performed good activity against Trichophyton mentagrophyte.

Table 1. Antifungal activity of extracts of $P$. jiring $a$ stem bark on two fungal strains at various concentrations

\begin{tabular}{lcccc}
\hline Fungi & $\begin{array}{c}\text { Concentration } \\
(\mathbf{m g} / \mathbf{m L})\end{array}$ & \multicolumn{3}{c}{ Extracts (Diameter of Inhibition Zone, mm) } \\
\cline { 3 - 5 } & 25 & $8.0 \pm 0.58$ & $12.0 \pm 0.58$ & $12.0 \pm 0.1$ \\
\hline Trychophyton mentagrophytes & 50 & $9.0 \pm 1.00$ & $13.0 \pm 1.53$ & \\
& 100 & $13.0 \pm 1.00$ & $19.0 \pm 1.53$ & \\
& 200 & $18.0 \pm 1.00$ & $23.0 \pm 1.00$ & \\
Candida albicans & 25 & - & - & $30.0 \pm 0.05$ \\
& 50 & - & - & \\
& 100 & - & - & \\
& 200 & - & - & \\
\hline
\end{tabular}

- sign no inhibition 
The antibacterial activity of the ethanol and ethyl acetate extracts of $P$. jiringa stem bark against two standard grampositive bacterial strains; Staphylococcus aureus and Staphylococcus epidermidis was investigated. Both of bacteria were the causative bacterium of skin disease in community acquired pneumonia and blood sepsis [9]. The result shown in Table 2 revealed the diameter of zone inhibition was dependent manner with concentration. It means, the higher the concentration of the extract, the larger diameter inhibition zone against microorganisms.

Table 2. Antibacterial activities of extracts of $P$. jiringa stem bark on two strains of bacteria at various concentrations

\begin{tabular}{llccc}
\hline Bacteria & \multirow{2}{*}{$\begin{array}{l}\text { Concentration } \\
(\mathbf{m g} / \mathbf{m L})\end{array}$} & \multicolumn{3}{c}{ Extracts (Diameter of Inhibition Zone, mm) } \\
\cline { 3 - 5 } & Ethanol & Ethyl Acetate & Ampicilin (Control) \\
\hline Staphylococcus & 25 & $8.0 \pm 0.58$ & $7.7 \pm 0.00$ & $18.0 \pm 0.1$ \\
aureus & 50 & $7.5 \pm 0.00$ & $8.2 \pm 0.58$ & \\
& 100 & $8.2 \pm 0.53$ & $9.5 \pm 0.58$ & \\
& 200 & $9.0 \pm 1.53$ & $11.7 \pm 1.53$ & \\
Staphylococcus & 25 & $6.0 \pm 1.00$ & $7.0 \pm 0.00$ & $37.0 \pm 0.05$ \\
epidermidis & 50 & $7.0 \pm 1.53$ & $12.0 \pm 0.58$ & \\
& 100 & $9.0 \pm 0.58$ & $11.0 \pm 1.53$ & \\
& 200 & $9.5 \pm 0.58$ & $13.0 \pm 0.58$ & \\
\hline
\end{tabular}

The microbial activity of Staphylococcus epidermidis had more efficiently inhibited towards the extracts than Staphylococcus aureus. This was revealed by the diameter of zone inhibition for all extracts. At highest concentration $(200 \mathrm{mg} / \mathrm{mL}), 13.0 \mathrm{~mm}$ was the largest inhibition zone of ethyl acetate extract was inhibited against Staphylococcus epidermidis compared to Staphylococcus aureus with $11.7 \mathrm{~mm}$ of zone inhibition. For the control activity, all solvents extract used as the negative control did not inhibit the bacteria. Meanwhile, the positive control, Ampicilin had strongly inhibited both bacteria; Staphylococcus aureus with $18.0 \mathrm{~mm}$ inhibition zone and Staphylococcus epidermidis, $37.0 \mathrm{~mm}$ inhibition zone. This means the extracts were active towards bacteria.

The phytochemical screening of the ethyl acetate and ethanol extracts studies on the stem bark of $P$. jiringa revealed that both crude extracts were rich in saponins, flavonoids, tannins and terpenoids but alkaloids does not present as shown in Table 3. These compounds have been known to be biologically active and therefore aid the antimicrobial activities of $P$. jiringa stem bark.

Table 3. Phytochemical screening test for $P$. jiringa stem bark extracts

\begin{tabular}{lccccc}
\hline & Alkaloids & Saponins & Flavonoids & Tannins & Terpenoids \\
\hline Ethyl acetate & - & ++ & + & ++ & ++ \\
Ethanol & - & ++ & + & ++ & ++ \\
\hline
\end{tabular}

++: strongly presence, + : presence, -: absence

Saponins were reported as a major components acting as antifungal secondary metabolite $[10,11]$. Therefore, saponins that found in stem bark of $P$. jiringa extracts have supported the usefulness of this plant in managing inflammation. Parekh and Chanda were reported that tannins are known to react with proteins to provide the typical tanning effect which is important for the treatment of inflamed or ulcerated tissues [12]. The presence of tannins in stem bark of $P$. jiringa shows its potential for treatment of different ailments. Flavonoids in $P$. jiringa stem bark extracts can exhibit a wide range of biological activities like antimicrobial, anti-inflammatory, anti-angionic, 
analgesic, anti-allergic, cytostatic and antioxidant properties [13]. Study done by Quinlan et al. revealed that some medicinal plants which exhibited antibacterial activities contained terpenoids compound [14]. Terpenoids are also responsible for the diverse pharmacological actions of the crude extract used.

\section{Conclusion}

Stem bark of $P$. jiringa contains important secondary metabolites (tannins, flavonoids, terpenoids, and saponins) thus has proven the therapeutic potentials of the plant. The screening of ethyl acetate crude extract of $P$. jiringa stem bark showed active activities against Staphylococcus aureus, Staphylococcus epidermidis and Trychophyton mentagrohytes. The largest diameter of inhibition zone for antibacterial is $13 \mathrm{~mm}$ which is moderately inhibited while for antifungal is $23 \mathrm{~mm}$ which indicates strongly inhibited. Therefore, it can be concluded that $P$. jiringa stem bark can be a potential source of active antimicrobial agents, and a detailed assessment of its in-vivo potencies and toxicological profile should be perfomed. This plant also appears to be the clinical, scientific, and pharmacologic basis for the use of herbal preparations. Further study on isolation and characterization of the active compounds from the crude $P$. jiringa stem bark extract is important for drug synthesis.

\section{Acknowledgements}

The authors would like to gratefully acknowledge the Biological Laboratory 3 of Universiti Teknologi MARA (Pahang) for their kind assistance in providing the strains of bacteria.

\section{References}

1. Bunawan, H., Dusik, L., Bunawan, S. N., M. and Amin, N. (2013). Botany, traditional uses, phytochemistry and pharmacology of Archidendron jiringa: A Review. Global Journal of Pharmacology, 7(4): 474-478.

2. Nahdzatul, S. M., Zeyad, D. N., Abdalrahim, F. A. A., Shafaei, A., Norshirin, I., Amin, M. S. A. M. and Zhari, I. (2012). Antiangiogenesis and antioxidant activity of ethanol extracts of Pithecellobium jiringa. BMC Complementary and Alternative Medicine, 12(1): 210.

3. Muslim, N. and Majid, A. (2010). Pithecellobium jiringa: A traditional medicinal herb. Webmed Central Complementary Medicine, 1 (12): 1371.

4. Ruzilawati, A. B., Imran, A. and Shaida, F. S. (2012). Effect of Pithecellobium jiringa as antimicrobial agent. Bangladesh Journal of Pharmacology, 7(2): 131-134.

5. Charungchitraka, S., Petsoma, A., Sangvanicha, P. and Karnchanatat, A. (2011). Antifungal and antibacterial activities of lectin from the seeds of Archidendron jiringa Nielsen. Food Chemistry, 126 (3): $1025-1032$.

6. Sule, W. F., Okonko, I. O., Omo-Ogun, S., Nwanze, J. C., Ojezele, M. O., Ojezele, O. J., Alli, J. A., Soyemi, E. T. and Olaonipekun, T. O. (2011). Phytochemical properties and in-vitro antifungal activity of Senna Alata Linn. crude stem bark extract. Journal of Medicinal Plants Research, 5(2): 176-183.

7. Ncube, B., Finnie, J. F. and Staden, J. V. (2012). In vitro antimicrobial synergism within plant extracts combinations from there South African medicinal bulbs. Journal of Ethnopharmacology, 139: 81-89.

8. Mutai, C., Bii, C., Rukunga, G., Ondicho, J., Mwitari, P., Abatis, D., Vagias, C., Roussis, V. and Kirui, J. (2009). Antimicrobial activity of pentacyclic triterpenes isolated from acacia mellifera. African Journal of Traditional, Complementary and Alternatives Medicines, 6(1): 42-48.

9. Sujana, P., Sridhar, T. M., Josthna, P. and Naidu, C. V. (2013). Antibacterial activity and phytochemical analysis of Mentha piperita L. (peppermint) — an important multipurpose medicinal plant. American Journal of Plant Sciences, 4: 77-83.

10. Onwuliri, F. C. and Wonang, D. L. (2003). Biochemical and antimicrobial studies of Zingiber officiale and Allium sativum on the selected microorganisms. B.Sc. Thesis, Department of Botany, University of Jos: 59.

11. Onwuliri, F. C. and Wonang, D. L. (2005). Studies on the combined antibacterial action of ginger (Zingiber officinale L) and garlic (Allium sativum L) on some bacteria. Nigerian Journal of Botany, 18: 224-228

12. Parekh, J. and Chanda, S. (2007). In vitro antibacterial activity of crude methanol extract of Woodfordia fruticosa Kurz flower (Lythacease). Brazilian Journal of Microbiology, 38(2): 204-207.

13. Hodek, P., Trefil, P. and Stiborova, M. (2002). Flavonoids - potent and versatile biologically active compounds interacting with cytochrome P450. Chemico-Biological Interactions, 139(1): 1-21.

14. Quinlan, M. B., Quinlan, R. J. and Nolan, J. M. (2002). Ethnophysiology and herbal treatments of intestinal worms in Dominica, West Indies. Journal of Ethnopharmacology, 80(1): 75-83. 